\begin{tabular}{cc}
\hline 臨 \\
\hline
\end{tabular}

\title{
下部胸椎，腰椎カリエス患者に認められた， 頭位に関連する誘発眼振（眩暈）
}

\section{（特に頭位眼振と頭位変換眼振について）}

\author{
吉井正清 - 坂倉幹 - 石橋樹 ・武藤康 正 $^{*}$
}

\section{I 緒言}

私達は最近，下部胸椎，腰椎カリエス患者，その経過中のある期間に亘つて，特定頭位（多くは 側頭位）に関連して誘発せられる眼振あるいは眩莗を訴えることが少くないのに気付いた。これら の際に認められた誘発眼振 (眩量) は一様のものでなく, その性状およびその原因的要素の点で相 異なる 2 種一一即ち, 一過性で頭位変換の運動的因子に由来するものと, 持続性で頭の位置それ自 体の静的因子に由来するものとの 2 種があつたが, 後者は, 明らかに頭位眼振（眩暈）と判定され る.

これらのすべてが皆単に治療に用いられだストレプトマイシンの 副作用のみから発来するとは考 え難い.

この様な誘発眼振 (眩暈) 特に頭位眼振 (眩暈)について，カリエス病变部位が頸椎ではなく， 下部胸椎，腰椎に存するものに出現することは注目を要する.

次に症例を記載し，いささか考察してみよう.

\section{II 症 例}

\section{症例 1 44才古 主婦}

患者は昭和30年より脊椎カリエスおよび，左結核性 股関節炎として治療を受けていたが，発病約 2 年 6 力 月後に突然, 右側頭位に際し激烈な回転性眩暈を訴 え，他覚的には下向性眼振が，その頭位をとる間持続 し，患者は苦痛のためこの頭位を持続することが不可 能であつた，而しながら以上の症候は約 1 力月後に自 然消退した。

聴力検査では気導，骨導共略正常，前庭機能にも左 右差は認められなかつた. 脊椎X線写真においては， B.W.11 B.W.12 L.W.1 L.W.2 に骨破壊像を認め, 自律 神経機能検査ではアドレナリン試験が陽性であつた。 後頭下穿刺における脳脊髓液は圧, 蛋白, 糖, 細胞数 共に異常を認めず，その他血液，尿，血圧等にも著変 を認めなかつた。
因に本例においては，腹部より左足関節迄ギプス包 帯を装着し，治療のためストレブトマイシンが眼振出 現迄に約 $160 \mathrm{~g}$ 使用されていた。

\section{症例 2} 37才古 主婦

昭和26年より胸椎カリエス (B.W.8.9) のため，コル セットを装着し，ストレプトマイシン $10 \mathrm{~g}$ の投与を受 けた患者であるが，カリエス発病 2 年を経て突然左側 頭位で強度の回転性眩最を訴え, 他覚的には持続性, 下向性，眼振を認めた。この眼振眩暈は約 2 力月間持 続した後自然に消退した。

聴器には異常を認めず聴力, 前庭機能は, 左右共略 正常であつた．自律神経系の症状としては眼振発来と 時期を同じくして顔面の紅潮，発汗が認められた。

症例 3 44 才古 主婦

昭和25年より脊椎カリエスおよび右鼠蹊部寒性膿瘍

* 三重県立大学医学部耳鼻咽喉科学教室 (主任 渡辺 篤教授) 
のためギプスペットを使用し，ストレプトマイシン約 $150 \mathrm{~g}$ の投与を受けて居たが，昭和34年 4 月突然右側 頭位で激烈な回転性眩量を訴え, 苦痛のため該頭位を とることが出来なくなつた．他覚的には右側頭位にお いて殆んぞ潜伏時間なくその頭位をとる間持続する頻 数の眼振 (下向性, 振巾中等度) を認めた.

聴器は両側鼓膜内陥混濁し, 聴力検査では気導で $6000 \mathrm{cps}$ 以上で急障を示した.

前庭機能は実験的眼振検查にて左右差殆んぞなく血 液, 尿にも異常なく知覚神経障害も認められない。自 律神経機能検査ではアドレナリン試験が强陽性であつ た.

脊椎 $\mathrm{X}$ 線写真では B.W.8 12 L. W 1 に及ぶ椎体全般 に亘り骨破罗像が認められた。

この患者における眼振および眩量は約 1 力月で自然 に消退した。

なお本例も眼振発現時の前後より, 顔面紅潮, 発汗 等がみられた。

\section{症例 430 才우 無職}

昭和24年考肺結核の診断を受け，人工気胸療法のみ を受けていたが，昭和 25 年 1 月左腸骨窩に膿瘍を.来 し, 脊椎X線撮影の結果 L.W.4·5 の骨破壊像が認めら れカリエスと診断され，ギプスベットを使用してい た.この間ストレプトマイシン等の化学療法は受けて いなかつたが，この頃より左側頭位で激烈な回転性眩 暈および上向性眼振が持続的に発現し，他の頭位をと ることによつてこの症候は消失した。

更に翌昭和 26 年 1 月には右側頭位をとつた際，一過 性に上向性眼振を来すと共に強度の回転性眩量を訴え る様になつたが，これは間もなく消失し，左側頭位に おける持続性眼振のみ継続して認められた。
昭和 26 年 2 月より化学療法が開始されストレプトマ イシン，パス，INAH，等が投与されたがそのために 眼振，眩暈は増悪あるいは軽快する様なこともなかつ た。昭和33年に至り両手指, 両足指, 趾に疼痛を訴え 紫紅色の斑紋を生じ，レイノ一氏病の疑いの下に現在 入院加療中である.

聴器は両側鼓膜正常であり, 実験的眼振検査におい て左右差は認められない，頭位検査において，左側頭 位をとつた際に殆んど潜伏時間なく，その頭位をとる 間持続する上向性眼振を認めた。

自律神経機能検査では, ピロカルピン試験強陽性, アトロピン試験陽性, アト゚レナリン試験陰性であつ た.

その他ソーンテストは+52.5\% 尿蛋白陽性の他血 液, 血圧, 䀒機能等に著变を認めていない. 左側頭位 における眼振は発来後約 2 年間が最も強度であつたが 次第に軽快しながら約 6 年間に亘つて認めることが出 来た。

\section{症例 5}

昭和25年腰椎カリエス (L.W.2.3) の診断を受け昭和 26年アルビー氏手術を施行され，一時軽快状態にあつ たが，昭和32年 7 月から 8 月にかけて左側頭位をとつ た際一過性に矓厙身体を振り廻される様な感じを訴え た.

昭和 33 年 3 月 $\mathrm{LW} .2, \mathrm{~L} . \mathrm{W} .3$ の病巣搔把術を受けた が，約 1 力月後に左側頭位をとると潜伏約 1 秒の後一 過性に振巾小，下向性の眼振を認め約 1 力月間持続し た.

耳疾患はなく，自覚的聴力は左右共正常で術後ギプ ス固定が行われ，ストレプトマイシン $50 \mathrm{~g}$ が使用され ている.

\section{III 総括ならびに考按}

1. 下部胸椎 (大体 B.W.7 以下) 腰椎カリエス患者 において，特定頭位に関連し誘発せられる眼振(眩暈) の報告は未だない.

これらの症候は相当の頻度で出現するものと思われ るが，ある期間経過すると自然に消退するので，今 日，多くは看逃がされているようである。

Pflatz and Lichter ${ }^{2)} は$ Cervicalsyndrom 85例 中20例に頭位眼振を，10例に自発および頭位眼振を認 めており，また朴沢他 ${ }^{3)}$ は頸椎異常によるメニエル氏 症候群の理学的療法による治験 3 例を報告してている が，我々の報告例は病変部位の点でこれらと同一視す
ることは出来ない（迷路支配の関係が異なる）

2. 誘発眼振の性状および種類

これらの際に認められた誘発眼振には明らかに性状 を異にする 2 者があつた。

(1) 僅かながら潜伏時を有し（1 秒前後）持続は一 過性, 弱度のものと,

(2) 認むべき潜伏時なく発現し，持続は長く（その 頭位をとる限り）強度のものとである.

前者はその発現の原因的要素が頭位とは云うもの の, 特定の頭位に至る頭位変換の運動的因子によると 考えられ，頭位変換眼振と称してもよいと思う. いづ 
れの方向に頭を運動ぜしめてもおこるもの例えば頭振 盜眼振年等は lockerungs Nystagmus としてここで は取り扱かわなかつた。

後者はその発現の系因的要素が，変化した頭位それ 自体に由来して erzeugen されるものと考えられる. 即ち, 明らかに頭位眼振〔狭義了に属するもので劣る。

後者を先学諸家の頭位眼振 分類に照合すると, Ruttin $^{5)}$ の II Gruppe, Seiferth ${ }^{6)}$, の Richtungs wechselnd, Nylén ${ }^{7)}$ の Typ I, Frenzel1) の Richtungs wechselnd regelmässig, 長谷川 ${ }^{8)}$ の下向性両 側性に相当する.

なお，頭位眼振についての， Barany ${ }^{9)}$ 以来数多い 交献は, 別篇（頭位眼振についての文献的考察 ${ }^{46)}$ ) に ゆずる。

(3) メニエル症との関係，および Lateralität の問 題

メニエル症患者に屚々，頭位眼振がみとめられると いうが (長谷川10), 内藤 ${ }^{11)}$, 大和田 ${ }^{12)}$ ) 私達の報告例 は, 症例 3 を除いて,メニエル症(狭義) とは考元難い.

Lateralität の問題は，メニエル症においても注目 されつつあるが (渡辺勈 ${ }^{13)}$ ，檜 ${ }^{14)}$ ) 私達の報告する誘 発眼振に関しても， Lateralitätをもつて発来するも のか否かという事は；その本質に触れる問題であろ う. 残念ながら, 病变左右別の明確な症例に接し得な かつたので，この問題の解明は今後の研究に俟ちた W.

\section{(4) 原因要素}

これらの誘発眼振 (眩暈) は頸部の条件とは無関係 （頭のみ位置を变えた際と, 頭と軀幹を共にして位置 を変えた際が同結果) に発生するので，頸反射，Vaskulär Fistelsymptom A. vertebralis の zuklemmen (Voss, Mygind, Borries, de Kleijn) 等による ものではない.

渡辺教授 ${ }^{199}$ は迷路瘦孔の圧迫性眼振の広沉な御業績 の中で, 頭部䵇血（特に瘦孔側血管結禁によるもの） が，最小適合圧を低下せしめ, 該眼振を量的に増加せ しめることを確認せられており, 又最近 Stenger ${ }^{20121)}$ は迷路㾇孔あるものに Lagefistelsymptom が認め られると報告しているが，我々の症例は Fistelsymptom を欠くので，これらとは別箇のものと思われ る.

既に，頸椎病変が聴覚および前庭機能に影響を及ほ すことは，古くは $\mathrm{Muck}^{22)}$ の報告があり，最近は Cervicalsyndrom (Barré et Lieou, Reischauer,
Bärtschi-Rochaix)の迷路症候 (Moritz, Wildhagen, Geiger, Aubry u. Pialoux, Mayoux) として広く

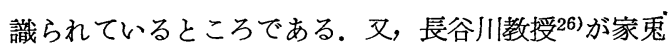
交感神経節摘出により, 頭位眼振 (異常頭位眼振) 惹 起に成功していることも衆知のところであろう.

然し乍ら, 私達の報告症例は, 病変部位が頸椎では なくて，ずつと下方の，下部胸椎，腰椎であるから， これらとは別箇のもので，その由来については新なる 考察が必要である.

さて, 下方の脊椎カリエス病変 (その手術的操作, 治療を含む）汃，前庭機能，とくに自発，誘発眼振に 影響を及漂す原因要素については, 種々の因が考えら れるが，特に考慮をなすべきは次の如きものであろ う.
(1)上行知覚系 (圧迫性髄膜炎)
(2)髄夜の異常（通過障害）
(3)腹部自律系（病変および手術の影響）
(4)皮膚刺㦸（高木）（ギプスおよびコルセット）に よる

(5)ストレプトマイシン副作用

(6)結核アレルギー

(1)星野教授 ${ }^{27)}$ は，頸部のみならず，胸腹腰部からの 上行知覚系もすべて前庭中枢核に側枝を与え，緊張性 脊䯣性眼反射に与かることを確証せられている. 張元 用 ${ }^{28)}$ の追試によれは, 脊髄後根の一側又は両側切断あ るいは麻㾇は，回転性眼振に一定の影響を及ほすが， 特発眼振を発来せずという。従つて上行知覚系に単独 ．に誘発眼振眩量の原因を求めることは稍困難とも思わ れるが，他の因子が共存する場合には或程度関係する ものと考える.

(2)䯋圧変動 (特に上昇) が前庭機能に一定の影響を 及注すことは, 矢野原 ${ }^{29}$, 安野, 斎藤30)草場311の報告

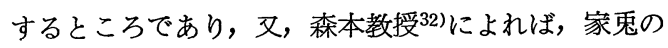
脳腔内に（迷路と freie Kommunikation）食塩水を 注入して，遂次脳圧を上げると，先ず頭位眼振が発来 し，後に自発眼振が起るという.

春椎カリエスにおいてはしかしながら，一般に䯣圧 は正常のことが多く, 症例 1 においても, 䯣圧, 性状 そもに正常であつた，従つて，䯋夜に関して，この際 問題となるのは，その通過障害ある場合で，むしろ特 殊な例についてのものと想像される. 即ち, 通過障害 がある場合には，頭位変換に際する頭蓋内圧変動 (Stenger) が，普通より強くあらわれるのではなかろ うか. 
従つて，一過性の頭位変換眼振 (眩量) の特殊例で のみ䯣夜通過障害が原因要素となり得ると考える.

(3)腹部自律樂が前庭機能に及ほす影響に関する系統 的研究は意外に䬥々たるものであるが, 臨床的経験か らは，消化系，性器系等と眩暈との密接な関連性から も，広く認められているところである。Percy ${ }^{33)}$ は消 化管から迷路への反射を, Wyburn ${ }^{34)}$ は胃腸障害と又 ニエル症候との関連を記載し，山川 ${ }^{355}$ 渭壁刺㦸によ り, 主として左側に向う特発眼振惹起を, 平田 ${ }^{36}$ は迷 走神経刺㦸による特発眼振発現を報告した.

若し N. Splanchinicus および胸，腰神経 $\rightarrow$ Grenz

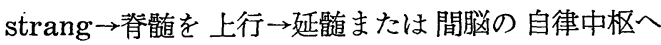
行くとすれば，下部胸椎，腰椎カリエス病変およびそ の合併症あるいはその手術的操作等が，その径路のい ずれかの部位に影響する可能性は大である.

症例 $1 ， 3$,における，アドレナリン試験陽性，症例 4 におけるピロカルピン試験およびアトロピン試験陽 性, あるいは症例 $2,3,4$ における誘発眼振 (矓量) 発 現と相前後して顔面紅潮発汗等の自律性現象の随伴は この考察の有力な根拠となりうるであろう.

(4)脊椎カリエスにおいては, 多くの場合, ギプス固 定文はコルセット装着が実施されている：従つて皮膚 刺戟の問題も亦考慮せるばなるまい。

高木 ${ }^{37338)}$ は圧迫皮膚反射の研究において，緊張性皮 膚反射の圧点は, 人上半身では腋窩点, 下半身では側 臂点であり，諸種の自律機能に大いなる影響を与える 事を認めている。 又，この緊張性反射は，家鬼におい ては, 片側刺战の際に, 眼筋緊張の不均衡（眼振の起 り易い状態）を来し，更に両眼の視覚を奪つた上，活 動性皮膚反射をも起さしめると Nystagmus jerk あ るいは眼振そのものが起るという。（皮膚性眼振）上 述の脊椎カリエス患者の誘発眼振が, 皮膚反射のみか ら惹起する可能性は，むしろ疑問と考えるが，少くと も眼筋緊張状態にある影響を与えること，また特に自 律機能に重大な影響を与えることは疑い得ないところ であろう。

(5)ストレプトマイシン副作用

(S.M. ストマイ，O.H.S.M. デヒドロストマイ，

S. M. およびその種の薬物が第 8 神経に強い親和性 を有することは衆知のところであり，副作用としての 前庭症状については, S.M.に比して, D.H.S.M. および， 複合剤が使用せられて以来減少したとはいうものの
(浅井3940))，それでもなお立木 ${ }^{411} は 400$ 例の D.H.S.M. 使用患者の $8.1 \%$ に眩量を認めている。私達の報告例 は，大多数 D.H.S.M. が使用せられている.

然しながら，一過性の眩量はともかく，頭位眼振の すべてが，ストレプトマイシン副作用のみから発生す るかは疑わしく, 事実, 我々の症例中には, ストレプ トマイシン使用以前に頭位眼振を認めたものもある.

(6)結核アレルギー

アレルギー性 前庭障害については，Skoog42)の «Forss manschen carotalen Syndroms》の実験 以来幾多の報告があり, 最近, 渡辺勈 ${ }^{43}$ はメニエル氏 症候群を，アレルギー及びストレス学説の見地から検 討した。

然し乍ら，特に結核アレルギーについては未だ詳細 な報告に接しない，池田 ${ }^{44}$ は，結核菌毒素による聴神 経炎に基く迷路性眩暈の 1 例を記載している.

なお，後藤(修)教授 ${ }^{45}$ は原因不明の内耳性難聴の中 には，結核アレルギーによるものが少くないことを主 張し，同教室の仲村，路次，日比野等は B.C.G. 注射 モルモットで，実験的追証をしているが，他方前庭機 能障害に関しては未だ詳細に解明されておらない。

なお，ストレプトマイシン副作用および結核アレル ギーについては，略々条件を同じくするものと考えら れる. 肺結核患者と脊椎カリエス患者について，比較 観察する必要があろう，然るに，肺結核患者において は脊椎カリエス患者とは異なり頭位変換眼振（眩量） を認めることはあつても，頭位眼振（眩暈）を認める ことは非常に稀れである.（目下統計的観察実施）

この事実から単にストレプトマイシン副作用あるい は結核アレルギーから本症候が発生するとは考察し難 w.

以上を要約すると，上述の(1)〜6はすべて，本症候 発生の原因要素たるの可能性が考えられるが，あるい は原因が単独ではなく，その内の 2,3 が共存すること も考慮せねばならぬ。

更に，頭位変換の動的な場合と，頭位それ自体の静 的な場合とでは, 自ら原因要素も異なるものであろ う. 未だ推察の域を脱せぬが我々の検查成績に徴し頭 位眼振矓暈については, 自律系異常が最も有力な要素 のようである.

本症候の原因要素の決定は, すべて今後の詳細な臨 床ならびに実験的研究に挨たねばなるまい。 
N 結 語

1. 下部胸椎, 腰椎カリエス患者において，頭位に関連して誘発せられる眼振（眩暈）が認めら れることがある。

2. この誘発眼振 (眩暈) は, 頭位変換眼振 (眩量) と, 頭位眼振 (眩暈) [狭義〕との 2 者に区 別すべきである。

3. 私達の症例においては病変部位が背椎の下方であるから，頸椎附近から誘発されるものと同 一視することは出来ない。

4. 本症候発生の原因的要素は複雑で, 単にストレプトマイシン副作用あるいは結核アレルギー のみから発生するとは考え難く, この他に, 上行知覚系, 髄液通過障害, 自律系異常, ギプスによ る皮膚刺㦸等も有力に関与することがあると考えられるが，その決定にはなお今後の研究を要しよ う.

御懇篤な御指導と御校閲を賜わつた恩師渡辺篤教授に深謝し，この小論文を同教授の満還歴の御誕生日に捧げ る.

1) Frenzel, H.: Spontan-und ProvokationsNystagmus als Krankheits Symptom [Springer-Verlag Berlin·Göttingen·Heidelberg] 1955

2) Pflatz, C. R. und Richter, H. R.: Archiv Ohren-usw. Heilk. u. Z. Hals-usw. Heilk. $172 ; 519,1958$.

3）朴沢二郎・他：耳㑨科 32；99, 昭35.

4) Moritz, W.: Z. Laryng. Rhinol. 30 ; 269, 1951

5) Ruttin, E.: Z. Hals-usw. Heilk. 27 ; 606, 1930

6) Seiferth, L. B. : Archiv. f. Ohren-usw. Heilk. 143 ; 52, 1937

7) Nylén, C.O.: Acta Oto-laryng. 31 ; 223, 1943.

8）長谷川高敏：耳喉科 $13 ; 750$, 昭 15

9) Bárány, R.: Mschr. Ohrenheilk. 47 ; 481, 1913.

10）長谷川高敏:耳喉科 $27 ; 805$, 昭 30.

11）内藤 儶: 日耳鼻 62 ; 増刊号 昭 34.

12）大和田健次郎：日耳鼻 62 ; 増刊号 昭34.

13）渡辺勈：日耳鼻 62 ; 増刊号 昭 34.

14) 檜 学: 日耳鼻 62 ; 増刊号 昭34.

15) Voss, O.: Verh. dtsch. Ges HNO-Ärzte Nürnberg s201, 1921.

16) Mygind, S.H. : Zeitshr. f. O. 77 ; 70, 1918.

要 文献

17) Borriés, G.V.T. : Acta Oto-Largngol. 1920 $\sim 21$

18) de Kleijn-Versteegh : Acta Oto-Laryngol. 6; 99, 1924.

19）渡辺 篤: 耳鼻臨床 $24 ; 324$, 昭 5 .

20) Stenger, H.H.: H.N. O.-Beihefte 3 ; 282, 1952

21) Stenger, H.H. : Archiv. Ohren-usw. Heilk, u. Z. Hals-usw. Heilk 168；220, 1955.

22) Muck, O.: Z. Hals-usw. Heilk. 30 ; 668, 1932.

23) Moritz, W : Mschr. Ohrenheilk. 87 ; 17, 1953.

24) Wildhagen, F. K. : Beih. z. H.N.O. Heilk. $3,139$.

25) Geiger. W.: Dtsch. med. Wschr. 1952, 198.

26）長谷川高敏：日耳鼻 $49 ; 110$, 昭 18.

27）星野貞次：耳鼻臨床 26 ；387, 昭7.

28）張元用：耳鼻臨床 31；1227, 昭11.

29）矢野原乃武：耳鼻臨床 $26 ； 409$, 昭 7.

30）安野吉郎・斉藤勤: 耳鼻臨床 $20 ; 317$, 大 15.

31）草場忠：日耳鼻 49；344, 昭18.

32）森本正紀：日耳鼻 $\mathbf{5 3 ； 4}$ 号-11 昭25.

33) Percy : A.J. Physiol. 87 ; 1928.

34) Wyburn. Masbon. R.: Brit. med. J. 79; 1959.

35）山川平作：耳鼻臨床 $29 ； 195$, 昭9. 
36）平田和夫：耳鼻臨床 26 ；101, 昭7.

37）高木健太郎：日耳鼻 57；1185, 昭29.

38）高木健太郎：最新医学 9; 639, 昭29.

39）浅井良三・他：耳鼻臨床 $43 ; 359$, 昭 25 .

40）浅井良三・他：耳喉科 $27 ； 886$, 昭 30.

41）立木孝・他：耳喉科 $28 ； 235$, 昭 31 .
42) Skoog, T.: Acta Oto-Laryng. suppl. 32 ; 1939.

43）渡辺觔：耳喉科 $27 ; 854$, 昭30.

44）池田四男：耳鼻臨床 47；497, 昭25.

45）後藤修二：日耳鼻 $\mathbf{5 5} ; 986$, 昭 27.

46）吉井正清：耳鼻臨床 $\mathbf{5 3}$; 近刊予定

掲載費著者負担（原稿受付 昭35.4.22.)

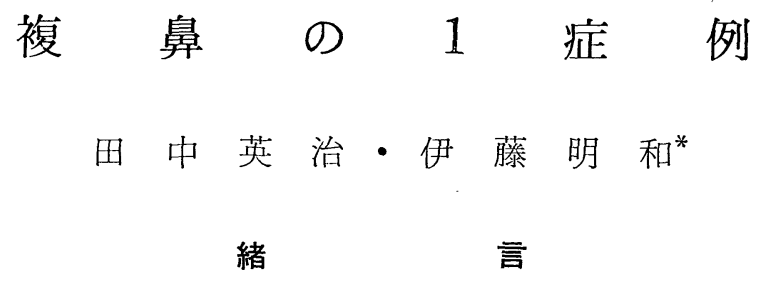

鼻科領域の先天性畸形としては従来鼻披裂症 Nasenspalte, 外鼻の部分的缺損（鼻翼缺損および 鼻中隔前部缺損) Defekt eines Teils der äusseren Nase (Nasenflugeldefekt und Defekt des vorderen Teils der Nasenscheidewand) 等が記載されているが他部の畸型に比して稀であり，特 に鼻披裂症の中でも鼻の重復形成 Doppelbildung d. Nase は極めて稀であつて，その中でも特に我 々がここに報告する如き形のものは我国においては未だその報告を見ず，外国においてもその報告 は極めて僅かである。

我々はか〉る「複鼻 Doppelnase」という非常に稀有なる先天性畸形の 1 症例に接したのでこ〉に 報告し諸賢の参考に資したい.

症

患者：1年 8 力月 古

主訴：鼻畸形

家族歴：父方に双生児を見る他に特記すべきものは ない。

既往歷：出産は正常にして生来健康.

現病歴：生来鼻畸形がある。呼吸および食物掑取状 態は正常であるが，鼻整形を希望して昭和 34 年 4 月 1 日名古屋大学矣学部附属病院耳鼻咽喉科外来に受診す る.

現症：発育栄養状態やや悪きも身体他部には畸形を みない。

局所所見：〔第1回〕[第 2 回]の如く右鼻腔は正常 に形作られ，前鼻鏡検査においても異常を見ないが,左 淠腔の外鼾口 (Hauptöffnung) は位置的に正常より 高位にあり，その左側下方にこれに比して大きさ小な
例

るもう 1 つ外鼻口 (Lateralöffnung) を見，そこに 消息子を挿入して探診すると左鼻腔に通ずる事が 分 る. なお左右両鼻腔は何れも咽頭に開口している. 又 上記 3 つ外鼻口は何れもそれを通じて空気が流通 し，漿液性分泌物を排泄している，後鼻鏡検査におい ては正常人の如く 2 つの大きい後鼻孔を見，かつ甲介 の端を観察し得, 亦鼻中隔の後端には異常を認めない. さらに眼所見としては左内眼㫮は下方に率引せられ た如き形を示しているが瞳孔反応および眼球運動は共 に正常, 眼底には異常を認めず，かつ眼球震盪もみら れない，その他においても眼科的に異常を認めない。

なお鼻橋下部より右上口唇にかけて浅い軗痕状の瑇 を見るが，この溝の達する部位において上口唇は菲薄 になつている。

口腔，咽頭，䐅頭には異常を認めない。へモグラム

* 名古屋大学医学部耳鼻咽喉科学教室 (主任 後藤修二教授)

$6-6$ 